\title{
Basic Erosion and Profit Shifting (BEPS)
}

\author{
Marco Lupi \\ Jonico Department, University of Bari Aldo Moro, Taranto, Italy \\ Email:lupimarco18@tiscali.it
}

How to cite this paper: Lupi, M. (2020). Basic Erosion and Profit Shifting (BEPS). Beijing Law Review, 11, 108-118. https://doi.org/10.4236/blr.2020.111007

Received: November 7, 2019

Accepted: January 19, 2020

Published: January 22, 2020

Copyright (c) 2020 by author(s) and Scientific Research Publishing Inc. This work is licensed under the Creative Commons Attribution International License (CC BY 4.0).

http://creativecommons.org/licenses/by/4.0/

\begin{abstract}
By Basic Erosion and Profit Shifting (BEPS) we mean the set of fiscal nature strategies that some companies put in place to erode the tax base (heroes base) and therefore deduct taxes from the tax authorities. The transfer of profits (profit shifting) from high-imposition countries to countries with no or reduced taxation is, in fact, itself a strategy that leads to the erosion of the tax base. Such practices are allowed: from aggressive tax strategies in contexts with a high rate of innovation, digitalization and globalization; from the rigidity of tax systems in the face of extreme "flexibility of corporate income"; from the possibility of separating the imposition of income sources from the economic activities that generate them; by the absence of coordination and by the presence of asymmetries between the different national tax regimes, for example in terms of a different treatment (for tax purposes) of the components of the company balance sheet (interest, dividends, etc.) and a non-uniform evaluation of the recurring items associated with intra-group and non-group transactions. The aim of this paper is to examine the new rules undecided by the OECD to counter the erosion of the tax base and the artificial transfer of profits-thus stemming the substantial capital outflows-to those countries that offer privileged taxation or, in the more extreme cases, towards tax havens.
\end{abstract}

\section{Keywords}

Shifting Profit, Base Erosion, Tax Distortions, Double Taxation, Transfer Pricing Rules

\section{Introduction}

The Finance Ministers and Governors of the G20 Central Banks, meeting in Lima, approved a package of measures to define a comprehensive, coherent and coordinated reform of international tax rules, thus expressing universal support for the Joint OECD Project-G20 on "Base Erosion and Profit Shifting" (so 
called BEPS Project). The results of which provide governments with a system of solutions to fill the gaps in current tax systems which, in fact, mean that corporate profits can escape taxation or be diverted, without taking into account the place where economic activity takes place underlying takes place, in national contexts with low or no taxation. At the last G20 meeting the Ministers renewed their commitment ${ }^{1}$ to implement the BEPS enforcement measures with the aim of presenting them at the G20 leaders' summit to be held on November 15-16 in Antalya, Turkey.

The package of measures to combat the BEPS constitutes the first and substantial reform of the international tax systems since these, about 100 years ago, were initially discussed and gradually introduced. The objective of the new tax order is to bring the taxation of corporate profits back into the countries where the activities take place and where the added value is actually created, so as to render the strategies of erosion of the tax base and the transfer of the assets ineffective. Profits made by some companies that, by exploiting obsolete rules and or poor coordination between the various national tax systems, reduce the tax revenue of individual countries (Bartelsman \& Beetsma, 2000).

\section{The Impact on Tax Revenue}

According to the OECD analysis, the BEPS subtracts huge resources from national economies that could be used to sustain growth, contribute to post-crisis consolidation plans, improve welfare policies in developing economies and, more in general, create fairer tax systems. According to the estimates carried out within the BEPS project, revenue losses can be estimated at between 100 and 240 billion dollars a year (88 - 211 billion Euros) or between 4 and 10 percent of the revenue global corporate taxation ${ }^{2}$ (Clausing, 2011).

Nevertheless, the evasive practices in question also affect trust in tax systems, have distortive effects on investment choices that are defined since aggressive tax strategies, rather than economic-productive reasons. The BEPS practices also create distorted incentives for the allocation of foreign direct investments, alter market dynamics by creating competitive advantages for multi-

\footnotetext{
${ }^{1}$ Cf. see what was already stated in the Communiqué of the G20 Finance Ministers and the Governors of Central Banks published after the meeting in Ankara (Turkey), "[...] We will continue to work on an equal footing as we monitor the implementation of the BEPS project outcomes at the global level, in particular the exchange of information on cross-border tax rulings. OECD to prepare a framework for early 2016 with the involvement of interested non-G20 countries and jurisdictions, particularly developing economies, on an equal footing. We welcome efforts by the IMF, WBG, UN and OECD to provide appropriate technical assistance to interested in developing economies in tackling the domestic resource mobilization challenges they face, including from BEPS. We continue to work on enhancing the transparency of our tax systems. We reiterate our commitment to implement the G20 High-Level Principles on Beneficial Ownership Transparency and look forward to further progress on country implementation. We support the efforts made for strengthening non-G20 economies' engagement in the international tax area and welcome decisions taken under the Addis Ababa Action Agenda on international cooperation on tax matters". ${ }^{2}$ OECD (2015), Measuring and Monitoring BEPS, Action 11-2015 Final Report, OECD/G20 Base Erosion and Profit Shifting Project, OECD Publishing, Paris. Le stime OECD sono sostanzialmente coerenti con quelle condotte dal FMI e dall'UNCTAD.
} 
national companies to the detriment of micro and small companies ${ }^{3}$ or large-scale businesses with businesses essentially domestic ${ }^{4}$.

The aim of this work is to illustrate what are the fundamental steps indicated by the OECD to tackle the phenomenon of BEPS or those tax planning strategies (Dischinger, Knoll, \& Riedel, 2014), that exploit the gaps in the tax rules to artificially move profits to places with low or no taxation where there is little or no economic activity. Some of these practices are illegal, some are not, but as pointed out by the OECD, these actions affect the fairness and integrity of the tax systems, because companies operating across borders can use tax base erosion and transfer practices of profits to obtain a competitive advantage compared to companies operating at national level (Degli Innocenti, 2016).

\section{Inadequacy of International Taxation}

The international tax system, inspired by the principles developed, since the 1920 s, by the Society of Nations, has been declined, in the last century, within the national regimes with the aim of reducing cases of double taxation and, hence, to limit the tax distortions seen as a limit to international trade and growth. Over the last decade, national legal systems have proved inadequate in coping with the aggressive tax practices of some companies operating on a global scale. In practice, the problem of double taxation has changed to that of double non-taxation.

The awareness of the need to face this order of problems was for the first time affirmed at the G20 Summit on June 18-19, 2012 in Mexico, where in the final declaration we can read the commitment of the Leaders "to prevent base erosion and profit shifting", a commitment that, with the G20 of the Ministers of Finance of 5-6 November 2012, translated into an explicit mandate to the OECD to deepen the theme. At the G20 in Moscow (19-20 July 2013). The OECD presented the Action Plan on Base Erosion and Profit Shifting report ${ }^{5}$, identifying an action plan, divided into 15 measures, aimed at analysing and addressing the issue on an international scale. It was presented on 16 September 2014 and finally on 5 October, in view of the G20 in Lima, the results of the entire BEPS project were published (Cerioni, 2015).

\section{Final Report}

The BEPS action package includes new minimum standards regarding: exchange of information between countries, with the aim of providing, for the first time, to the administrations finance a global framework of strategies implemented by multinational companies (Cipollina, 2014), abuse (use) of the treaties, to put an end to the exploitation of vehicle companies with elusive purposes; limitation to ${ }^{3}$ OECD studies (cf. note 3 ) highlight how the BEPS strategies implemented by some multinationals allow reducing the weight of taxation to a minimum of 5 per cent against an average rate of 30 per cent on the small firms.

${ }^{4}$ The advantage in terms of effective tax rates is quantifiable in a range of 4 to 8.5 percentage points.

${ }^{5}$ Presentation of the BEPS Action Plan Report. 
harmful tax practices, particularly in the field of intellectual property (Evers, Miller, \& Spengel, 2015); automatic exchange of information in tax agreements between multinationals and countries (ruling); agreements between tax administrations in order to prevent double-non-taxation actions being translated into double taxation (Dorigo \& Mastellone, 2015).

Furthermore, the BEPS Package reviews the transfer pricing guidelines, with the aim of preventing recourse to the so-called. "Cash box" to subtract taxable tax base and redefines the concept of stable organization to put a brake on the practices of erosion of the tax base made possible by the previous notion ${ }^{6}$.

The reports presented contain recommendations aimed at introducing changes in national tax laws, in the OECD model of the tax agreement (the OECD model) and in the guidelines for transfer pricing (Bergmann, Grothe, \& Treidler, 2015). Finally, it is recommended to speed up the process of transposing the proposal for the adaptation of bilateral treaties through the instrument of the multilateral convention, already successfully used in other areas.

\section{The 15 Steps $^{7}$}

\subsection{Introduction}

The Action Plan illustrates 15 actions considered fundamental to concretely achieve the goals of the BEPS Project.

Actions 2 to 14 are divided into three columns:

1) give consistency to national tax regimes regarding transnational activities;

2) reinforce the substantive requirements underlying the current international standards, pursuing a realignment of taxation (and tax regimes) with the substantial location of production activities and the creation of value;

3) increase transparency, exchange of information and improve the conditions of legal certainty both for the business world and for governments.

Two further transversal actions complete the strategy and, ideally, represent the basis on which the three pillars rest: this is the first action about digital economy and the last (15) on the use of a conventional instrument of multilateral type.

\subsection{Transversal Actions}

\section{Action 1-Digital Economy}

The report on Action 1 concludes with the statement that the digital economy cannot be circumscribed and separated from the rest of the economy, because it represents the economy itself. The current system of fiscal rules and procedures, at national and international level, is often not capable of satisfactorily intercepting, and therefore subjecting entirely to taxation, the incomes produced by the large multinationals operating in the regularly. Therefore, developing a suit-

${ }^{6}$ Cash boxes are companies, located in countries with favourable tax jurisdiction, in which profits are transferred as a result of business activities conducted in high-tax countries.

${ }^{7}$ BEPS Action Plan Final Report (2015). 
able tax discipline concerning the digital economy constitutes a topic of great importance that, moreover, presents profiles of considerable complexity. The characteristics of the digital economy actually require the introduction of a more general approach, which invests the assumptions themselves of the imposition and its distribution between the various jurisdictions: today there are in fact various possibilities for reducing the load tax, of the erosion of the tax base and of the transfer of profits in the countries with lower taxation, whose impact is amplified by the high degree of dematerialisation that the CDs contain. digital enterprises. In particular, it is necessary to take into consideration, given the considerable divergence between the place where the sale of digital goods and services takes place and that of the taxation of the related income, forms of taxation that are independent of the presence of a taxable presents, usually identified with a stable organization, in the territory of the states in whose markets the digital multinationals are active. One possibility is to use as a reference concepts such as the "significant digital presence" of a particular company in the economy of the territory of a State other than the residence one or the "stable virtual organization", useful for the purpose of verifying the existence of the requisites deemed qualifying a series of additional or divergent parameters with respect to the traditional ones, as well as the concept of "link" with the territory. A possible change also concerns the possibility of dividing the profits of a group among the countries taking into account the multiple factors that contribute to determining the wealth involved and intertwined with a series of themes that are the subject of other actions, such as for example the definition of a stable organization, the phenomenon of transfer pricing and the rules on foreign subsidiaries.

Action 15-Multilateral Instrument ${ }^{8}$

This action aims to develop a multilateral instrument to modify bilateral agreements, with the aim of speeding up and facilitating the implementation of the measures developed to deal with the elusive phenomena. In fact, it is necessary to prefigure methodologies that allow tax regimes to be adapted promptly in response to the rapid evolution that characterizes the global economy. The report shows that, although the scope was not that of taxation, there are nevertheless several precedents, in the context of international law, for changes to bilateral treaties through multilateral instruments.

\subsection{First Pillar}

Action 2. Hybrid Mismatch Arrangements ${ }^{9}$

Neutralize the effects of the c.d. hybrid mismatch arrangements, intended as tools and strategies that aim to exploit the asymmetries between the different national regulations in order to determine situations of undue advantage. These are, for example, "double non-taxation", multiple deductions in relation to the same expense, deduction in a country of taxes never paid elsewhere, long-term deferral of the payment of taxes due.

${ }^{8}$ Action 15-Developing a Multilateral Instrument to Modify Bilateral Tax Treaties.

${ }^{9}$ Action 2-Neutralise the Effects of Hybrid Mismatch Arrangements. 


\section{Action 3. Rules on Foreign Subsidiaries ${ }^{10}$}

Define clear rules about foreign subsidiary regulations (Controlled Foreign Company-CFC Rules), starting from the definition of the same and their requirements. The recommendations made by the OECD are aimed at avoiding the fictitious shift of significant incomes towards foreign subsidiaries resident in countries with privileged taxation. It is a matter of defining with extreme precision the concept of control and the date on which the requisites object of the relative verification must exist.

Action 4. Intercompany Financial Transactions ${ }^{11}$

Limit the erosion of the tax base deriving from the deduction of interest and other costs related to financing carried out within multinational groups, introducing percentage thresholds that cannot be exceeded, for the usability of tax benefits deriving from the presence of debt.

\section{Action 5. Harmful Tax Practices ${ }^{12}$}

The BEPS Project provides for a restructuring of the work on harmful tax practices, increasing transparency and highlighting the substance of the operations, as well as using shared methods in establishing minimum standards to be respected in order to take advantage of favorable regimes. To this end, a mandatory exchange of information between countries is required about the decisions concerning the subsidized schemes in force and the related procedures.

\subsection{Second Pillar}

\section{Action 6. Anti-Abuse Clauses ${ }^{13}$}

Prevent, through specific anti-abuse clauses, the granting of benefits in inappropriate circumstances, by virtue of what is allowed by the conventions against double taxation. We refer, in particular, to the definition of minimum standards to avoid the c.d. "treaty shopping", which occurs when a person who does not reside in either of the two states that have signed a tax treaty seeks to obtain the benefits that the treaty reserves for residents. These strategies are often implemented giving rise to the territory in relation to which the desired benefits are in force for fictitious companies (called "letterboxes", "shell companies", "conduits"), almost completely non-existent in terms of substance.

Action 7. Stable organization ${ }^{14}$

The changes in relation to Action 7 concern the definition of a new and more articulated concept of stable material and personal organization that considers the recent market dynamics. It is an example of making the elusive technique consisting in replacing distributors with "commissionaire arrangements" ineffective, with consequent shift of profits from the country; as well as the strategies of fragmentation of commercial activities between closely related companies.

\footnotetext{
${ }^{10}$ Action 3-Designing Effective Controlled Foreign Company Rules.

${ }^{11}$ Action 4-Limiting Base Erosion via Interest Deductions and Other Financial Payments.

${ }^{12}$ Action 5-Countering Harmful Tax Practices More Effectively, Taking into Account Transparency and Substance.

${ }^{13}$ Action 6-Preventing the Granting of Treaty Benefits in Inappropriate Circumstances.

${ }^{14}$ Action 7-Preventing the Artificial Avoidance of Permanent Establishment Status.
} 
With reference to the permanent personal organization, it is necessary to avoid that those who, in fact, continuously hold the power to conclude contracts in the name of a foreign company can be considered independent agents.

\section{Actions 8 - 10. Transfer Pricing ${ }^{15}$}

Actions 8 to 10 are aimed at ensuring that the transfer pricing rules ${ }^{16}$ within the multinationals allow the determination of an adequate allocation and taxation of profits, in line with the economic activities that generated them. Indeed, there is a tendency on the part of some multinationals to make profits emerge where it is possible to enjoy greater advantages from the fiscal point of view and not where the business activity takes place. In this respect, the existing Guidelines, inspired by the principle of market price in the transfers between associated companies, were found to be susceptible to manipulation. It is therefore a question of updating the Transfer Pricing Guidelines, through appropriate corrective amendments aimed at integrating the existing provisions.

Action 8 considers the issue of transfer pricing in relation to transactions involving intangible assets, given that the latter are mobile and normally difficult to assess.

Action 9 provides for the allocation of risks on a contractual basis to be considered as such only in the presence of the effective possibility of the associated company to make decisions, to exercise control over the risk itself and to be able to deal effectively with own resources.

Action 10 focuses on high-risk areas for the purpose of erosion of the tax base through strategies such as the fictitious increase in management costs compared to their actual size.

\subsection{Third Pillar}

Action 11. Measure the BEPS ${ }^{17}$

This action aims to measure the dimensions of the phenomenon, through a dashboard of six indicators, and to monitor both its evolution over time and the effectiveness of the strategies adopted for its contrast. This also through the improvement by the individual States of data collection and analysis activities (Garbarino \& Turina, 2015). For this last purpose, the report provides a guide so that the appointed public officials can estimate the effects of the different actions identified and the measures adopted within their own country.

\section{Action 12. Rules of Disclosure ${ }^{18}$}

This action concerns the methodologies that can be used to become aware of the phenomena of aggressive tax planning by taxpayers, also through the obligation to declare in this sense by the same, under various possible forms. The financial administrations of the various countries are provided with a structure that can be modulated on the basis of specific needs aimed at the timely collec-

\footnotetext{
${ }^{15}$ Actions 8-10-Aligning Transfer Pricing Outcomes with Value Creation.

${ }^{16}$ Transfer price applied in transactions with associated companies.

${ }^{17}$ Action $11-$ Measuring and Monitoring BEPS

${ }^{18}$ Action $12-$ Mandatory Disclosure Rules.
} 
tion of information useful for identifying these phenomena, to then analyse the patterns found in the concrete experience and undertake as soon as possible law enforcement activities.

\section{Action 13. Documentation on Transfer Pricing ${ }^{19}$}

Improve and coordinate in a more articulated way the documentation requested of multinational companies in terms of transfer pricing and proceed to the identification of a minimum standard, requiring taxpayers to indicate the taxes paid in the various States, so that the individual administrations of the countries involved are facilitated in identifying areas at risk of avoidance and in properly addressing their control activity. The creation of a master file is envisaged which can be accessed by the Administrations of the main countries, a local file for each country and a Country by Country report; the latter is intended as a tool through which multinationals are required to provide annually, separately for each jurisdiction with reference to the countries in which they operate-information on income, taxes paid and other specific predefined indicators (Adams, Evans, \& Martin, 2015).

Azione14. Dispute Resolution ${ }^{20}$

The purpose of the action is to make the dispute resolution mechanisms more effective, also in consideration of the fact that the changes introduced by the BEPS Project could be likely to determine elements of uncertainty in the short term, with possible repercussions in terms of increase in litigation, for example with regard to double taxation. A standard has been established whereby countries undertake to try to resolve disputes in an average time frame of months. 11 best practices have also been identified to which reference can be made.

\section{The Results of the BEPS Project: The 2017 Multilateral Convention}

On 7 June 2017, 67 countries signed the Multilateral Convention to Implement Tax Treaty Related Measures to Prevent Base Erosion and Profit Shifting-MLI at the OECD headquarters. The signing of the multilateral convention will allow for the introduction of the measures developed in the BEPS project into bilateral treaties, allowing governments to strengthen their network of treaties effectively and consistently without resorting to expensive bilateral negotiations.

The Convention is based on some key principles: firstly, it applies in relation to the treaties that both Contracting States have notified to the OECD for this purpose; the so-called BEPS minimum standards apply automatically, with few exceptions, to all treaties that have been notified and when these standards can be met with different solutions, the parties must try to identify one that satisfies each other; then, in relation to the provisions that do not constitute minimum standards, each contracting country can express a reservation that prevents their application; Furthermore, in some cases, the Convention provides for alternative options which will be applicable only if both contractors expressly choose to do so.

\footnotetext{
${ }^{19}$ Action 13-Transfer Pricing Documentation and Country-by-Country Reporting.

${ }^{20}$ Action 14-Making Dispute Resolution Mechanisms More Effective.
} 
Consequently, its provisions can be classified into three main categories:

1) Those which constitute the minimum necessary level of alignment of the treaties, i.e. the so-called minimum standard. For example: a preamble establishing the intent of the treaty to eliminate double taxation but also to avoid double non-taxation; the Principal Purpose Test (PPT) clause to prevent abuse of the treaty; and the commitment of the parties to apply a friendly procedure (MAP-Mutual Agreement Procedure) for the resolution of disputes.

2) Those that will be applicable by the contractors after the necessary ratifications, and provided that no reservations have been expressed on the point, without the need for an explicit choice. For example: the rules on income relating to transparent entities, on the granting of the benefits of the treaty to entities with double residence, on transactions relating to the transfer of dividends, on profits attributable to permanent establishments located in third jurisdictions and on the artificial circumvention of stable status organization.

3) Those that are not applicable without the expression of a specific will of the parties. For example: the options on the application of the methods for the elimination of double taxation, on the contrast to the artificial circumvention of the status of permanent establishment through exemptions for specific activities, on the simplified provision of the limitation of benefits and on the consent to the introduction of a mandatory and binding arbitration.

These distinctions make us understand how the Convention represents a balance point reached between the need to be effective and the opportunity to be a flexible tool, thus attractive to as many countries as possible, despite the political, cultural and of the tax system.

Once the Convention has entered into force, the Convention generally becomes effective for tax periods starting after the next six months, or for taxes withheld at source from the beginning of the following calendar year. However, there are several options that the contracting jurisdictions can exercise to depart from the aforementioned general rule, for example they can adopt a shorter latency period than six months if they notify the Depositary that they intend to apply a shorter period.

The OECD is the depositary of the multilateral convention and supports governments in the process of signing, ratifying and implementing. The position of each signatory under the Convention is available on the OECD website.

The first changes to the existing tax treaties could enter into force at the beginning of 2018, although it is reasonable to think that the effects will become fully visible over the next few years. This new tool is a decisive step towards the implementation of the results of the BEPS Project in thousands of tax treaties around the world and will allow the acceding States to strengthen their treaty network with the new measures launched under the BEPS Project (Romano \& Sencar, 2016).

\section{Conclusion}

Some of the measures contained in the BEPS package will be immediately applicable, such as the aforementioned new guidelines on transfer pricing, while oth- 
ers will require a review of national regulations and bilateral tax treaties, regarding action 15, as mentioned, which suggests the use of a multilateral instrument that makes it possible to avoid having to sign up to hundreds of bilateral treaties and at the same time guarantees conditions of greater uniformity of application.

The report clarifies that taxation remains an area of national sovereignty; however the obligation not to conflict with the commitments made at the international level places a concrete limit to the differentiated implementation.

The collaboration of the different countries is expected to continue until 2020 to complete the various lines of activity (Zielke, 2014).

At a national level it is recalled that the legislative decrees implementing the fiscal delegation have introduced various innovations, also taking advantage of the first results of the BEPS Project, with reference for example to the regulation of the permanent establishment, to the transfer pricing (Albano \& Bellini, 2015), to the aforementioned ruling, (see Legislative Decree 147/2015); to abuse of the right, doubling of the terms for the assessment, and collaborative compliance (cooperative compliance) (see Legislative Decree 128/2015). The collaborative compliance approach formulated by the OECD in 2013 constitutes an update of the previous (2008) cd. enhanced relationship inspired by a climate of mutual trust (Rossi-Maccanico, 2015).

Precisely with reference to this last profile, in order to promote a relationship between tax payers and tax administrators, based on trust and collaboration, aimed at increasing the spontaneous compliance rate and preventing litigation, the MEF announced in October 2015 the contribution to the IMF and the OECD for an assignment to identify international best practices on tax payer relations that could be introduced in Italy (De Simone, 2015).

\section{Conflicts of Interest}

The author declares no conflicts of interest regarding the publication of this paper.

\section{References}

Adams, T., Evans, J., \& Martin, E. (2015). Key Questions for Companies Preparing for OECD Guidance Under BEPS Action 13. Tax Management Transfer Pricing Report.

Albano, G., \& Bellini, M. (2015). Il Transfer Price supera i contratti (p. 19). Il Publisher Sole 24 Ore, Norme e Tributi.

Bartelsman, E. J., \& Beetsma, R. (2000). Why Pay More? Corporate Tax Avoidance through Transfer Pricing in OECD Countries. Tinbergen Institute Discussion Paper.

Bergmann, G. R., Grothe, B., \& Treidler, O. (2015). A Lesson from BEPS: Minimize Transfer-Pricing-Related Tax Risks. Tax Notes International, 79, 1047-1052.

Cerioni, L. (2015). The New "Google Tax": The "Beginning of the End" for Tax Residence as a Connecting Factor for Tax Jurisdiction? European Taxation, Amsterdam, 55, 185-195.

Cipollina, S. (2014). I redditi "nomadi" delle società multinazionali nell'economia globalizzata. Rivista di Diritto Finanziario e Scienza delle Finanze, 1, 21-63. 
Clausing, K. A. (2011). The Revenue Effects of Multinational Firm Income Shifting. Tax Notes, 28, 1580-1586.

De Simone, L. (2015). Does a Common Set of Accounting Standards Affect Tax-Motivated Income Shifting for Multinational Firms? Journal of Accounting and Economics, 61, 145-165. https://doi.org/10.1016/j.jacceco.2015.06.002

Degli Innocenti, N. (2016). Un taglio delle imposte per trattenere le imprese (p. 13). Publisher Il Sole 24 Ore.

Dischinger, M., Knoll, B., \& Riedel, N. (2014). The Role of Headquarters in Multinational Profit Shifting Strategies. International Tax and Public Finance, 21, 248-271. https://doi.org/10.1007/s10797-012-9265-5

Dorigo, S., \& Mastellone, P. (2015). L'evoluzione della nozione di residenza fiscale delle persone giuridiche nell'ambito del progetto BEPS. Rivista di Diritto Tributario, 3, 35-75.

Evers, L., Miller, H., \& Spengel, C. (2015). Intellectual Property Box Regimes: Effective Tax Rates and Tax Policy Considerations. International Tax and Public Finance, 22, 502-530. https://doi.org/10.1007/s10797-014-9328-x

Garbarino, C., \& Turina, A. (2015). Il progetto BEPS e gli "Hybrid Mismatch Arrangement": Un esame del relativo "Deliverable". Fiscalità e Commercio Internazionale, 5, 20-31.

Romano, C., \& Sencar, D. (2016). “Country-by-Country Reporting”: Origini, contenuti e prospettive. Corriere Tributario, 11, 821-827.

Rossi-Maccanico, P. (2015). Fiscal State Aid, Tax Base Erosion and Profit Shifting. EC Tax Review, 24, 63-77.

Zielke, R. (2014). Transfer Pricing of Mayor EC Member Countries with Reference to the 2014 Corporate Income Tax Burden of the Thirty-Four OECD Member Countries. 